\title{
Heart on the wrong side
}

\author{
John O’Bryen, Nirija Ranjit Anderson, \\ Joel Collins

\section{CASE}

A man aged 19 years presented to a general practitioner (GP) with a one-day history of urinary frequency. There was no associated dysuria, macroscopic haematuria or urethral discharge. His history was unremarkable for previous urological conditions and sexual activity. On examination he was afebrile at $36.7^{\circ} \mathrm{C}$. His abdomen was soft with no palpable masses, and examination of his genitalia was normal. A digital rectal examination was not performed. A urine dipstick indicated the presence of nitrites, leucocytes, blood and protein. A provisional diagnosis of urinary tract infection was made. The specimen was sent for microscopy, culture and sensitivities (MCS). The patient was prescribed trimethoprim $300 \mathrm{mg}$ daily for seven days and advised he would need a follow-up appointment to discuss the MCS results and to arrange ultrasonography of his kidneys, ureters and bladder.

Incidentally, the GP noticed that the patient had a marfanoid appearance and obtained consent to examine for this. The patient's height was $195.5 \mathrm{~cm}$ and weight was $64.3 \mathrm{~kg}$, giving a body mass index of $16.82 \mathrm{~kg} / \mathrm{m}^{2}$. He had long limbs with low muscle volume and long digits with hyperextendable joints. Inspection of the anterior chest revealed pectus carinatum and, to the GP's surprise, a bounding apex beat on the right side of the chest within the fifth intercostal space. The patient's left hemithorax was dull to percussion and had no breath sounds to auscultation. He was not tachypnoeic and had no increased work of breathing. It was noted that the patient was diaphoretic.
On further questioning, the patient admitted to worsening exertional dyspnoea for one month with associated orthopnoea when sleeping on his right side. He had also had a non-productive cough for the same duration. He had not sought medical advice for these symptoms as he attributed them to smoking, having smoked five cigarettes daily for the previous 1-2 years. He had not had any weight loss, had not travelled internationally and did not use recreational drugs. His alcohol intake was minimal.

The GP expressed concern about a sinister thoracic pathological process and requested the patient have a chest $\mathrm{X}$-ray performed that afternoon. Despite telephone call reminders, the patient delayed the X-ray (Figure 1) until the following week because of commitments, and in this time he had increased exertional dyspnoea.

\section{QUESTION 1}

What are possible causes of a pleural effusion?

\section{ANSWER 1}

The causes of a pleural effusion are typically considered under the categories of transudates and exudates (Table 1) on the basis of assessment of the pleural fluid according to Light's criteria. ${ }^{1}$

\section{CASE CONTINUED}

The GP was contacted by the radiologist to discuss the chest $\mathrm{X}$-ray findings. They proceeded immediately to a computed tomography (CT) scan of the chest, abdomen and pelvis (Figure 2), which provided additional findings of widespread lymphadenopathy, hepatosplenomegaly and sclerotic bone lesions. A provisional diagnosis of lymphoma was made on the basis of these findings; the patient was telephoned by the GP to inform him of the results and to arrange inpatient hospital admission via emergency. Formal urine MCS results, which identified a significant number of erythrocytes with no leucocytes and no pathogen isolated on culture, were also discussed. The urinary frequency and microscopic haematuria were attributed to the suspected lymphomatous process. During hospital admission, an additional history was elicited of three months of night sweats; an episode of epistaxis; and examination findings of palpable cervical, supraclavicular and axillary lymphadenopathy.

The patient was admitted under the haematology unit and thoracentesis was performed. Work-up identified several abnormalities including hypercalcaemia,

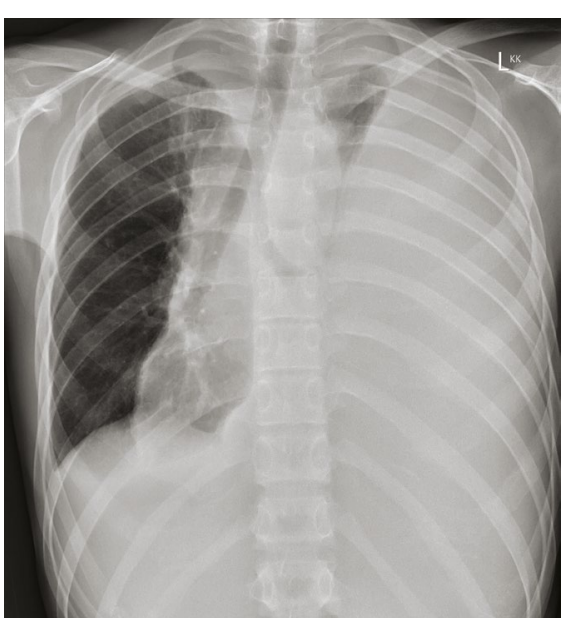

Figure 1. Chest $X$-ray showing a large left pleural effusion and mediastinal shift to the right 
anaemia, coagulopathy, raised lactate dehydrogenase and raised C-reactive protein (Table 2). A cervical lymph node biopsy confirmed classical Hodgkin lymphoma. Staging was consistent with stage IV (advanced-stage Hodgkin lymphoma). The patient commenced doxorubicin, bleomycin, vinblastine, dacarbazine (ABVD) as his initial treatment regimen because of the ability to administer it rapidly. He was subsequently escalated to bleomycin, etoposide, doxorubicin, cyclophosphamide, vincristine, procarbazine, prednisolone (BEACOPP) for a planned six cycles. The GP arranged a referral to clinical genetics to pursue the Marfan diagnosis; however, the patient moved interstate and did not follow this up. Continuation of management of his lymphoma was transferred to his local haematology service.

\section{QUESTION 2}

What are typical presentations of Hodgkin lymphoma?

\section{QUESTION 3}

How is the diagnosis of Hodgkin lymphoma confirmed?

\section{QUESTION 4}

What is the staging system used?

\section{QUESTION 5}

What is the significance of Marfan syndrome?

\section{ANSWER 2}

Typical presentations of Hodgkin lymphoma are asymptomatic lymphadenopathy, a mediastinal mass or 'B symptoms' (fever $>38^{\circ} \mathrm{C}$, weight loss and drenching sweats). A doctor must examine for lymphadenopathy and splenomegaly if these conditions are suspected. Hodgkin lymphoma has a bimodal age distribution with peaks among young adults and the elderly.

\section{ANSWER 3}

Histopathological diagnosis is required via tissue sampling, ideally using an
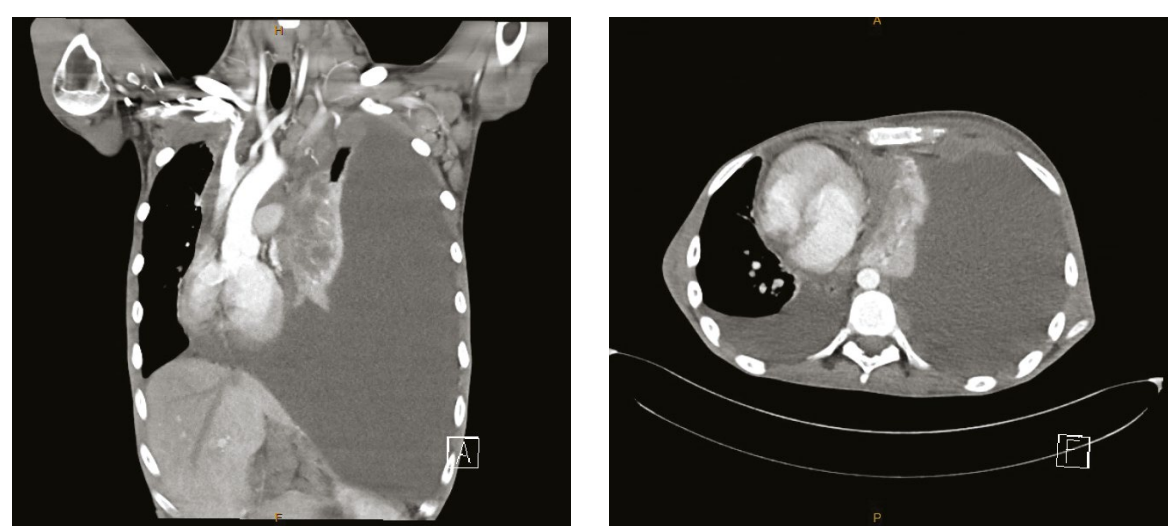

Figure 2. Computed tomography of the chest

\section{Table 1. Causes of pleural effusions}

\begin{tabular}{lll}
\hline Transudates & Exudates & \\
\hline - Heart failure & - Pneumonia & \\
- Liver cirrhosis & $\cdot$ Malignancy & - Tuberculosis \\
- Kidney failure & - Pancreatitis & $\cdot$ Chylothorax \\
- Hypoalbuminaemia & $\cdot$ Autoimmune disease & $\cdot$ Medications \\
& $\cdot$ Pulmonary infarction & \\
\hline
\end{tabular}

excisional lymph node biopsy. A positron emission tomography/CT scan is required for staging, and a bone marrow biopsy is performed to assess marrow involvement.

\section{ANSWER 4}

The Cotswolds-modified Ann Arbor classification is used for staging. ${ }^{2}$ Stages are from I to IV with further sub-classifications. Patients may have early-stage disease (limited - stages I and II) or advanced-stage disease (stages III and IV). Early-stage disease is sub-classified into favourable and unfavourable depending on the presence of B symptoms, age and bulky disease. Disease stage is prognostic, in addition to several other patient parameters including age, sex and haematological parameters. Five-year survival for advanced-stage Hodgkin lymphoma ranges from $67 \%$ to $98 \%$ based on the patient's International Prognostic Index score with ABVD treatment, and similar rates are reported for BEACOPP regimens. ${ }^{3}$

Given the favourable survival rates for patients with even highest-stage disease - especially in the fit, young patient population - a key focus is now management and prevention of longer-term therapy-related toxicities such as cardiopulmonary complications, as well as monitoring for secondary malignancies that may occur as a late complication of therapy. ${ }^{4}$ Novel targeted therapies currently in clinical trials promise to provide additional treatment options and reduce therapy complications. ${ }^{5}$

\section{ANSWER 5}

Individuals with Marfan syndrome should undergo monitoring for aortic dilatation, ectopia lentis, glaucoma, scoliosis and pectus deformities. They should receive genetic counselling and advice regarding appropriateness of pregnancy and high-intensity exercise given the risk of aortic dissection. ${ }^{6}$ There is suggestion that Marfan syndrome is associated with higher rates of malignancy. ${ }^{7}$

\section{Key points}

- Typical presentations of Hodgkin lymphoma are asymptomatic 


\section{Table 2. Pathology results}

\begin{tabular}{|c|c|c|}
\hline Observation & Value & Reference range \\
\hline Haemoglobin & $116 \mathrm{~g} / \mathrm{L}$ & $135-180 \mathrm{~g} / \mathrm{L}$ \\
\hline White cell count & $9.8 \times 10^{9} / \mathrm{L}$ & $4.0-11.0 \times 10^{9} / \mathrm{L}$ \\
\hline Platelet count & $367 \times 10^{9} / L$ & $140-400 \times 10^{9} / \mathrm{L}$ \\
\hline Haematocrit & 0.37 & $0.39-0.52$ \\
\hline Red cell count & $4.60 \times 10^{12} / L$ & $4.50-6.00 \times 10^{12} / \mathrm{L}$ \\
\hline Mean corpuscular volume & $81 \mathrm{fL}$ & $80-100 \mathrm{fL}$ \\
\hline Neutrophils & $8.80 \times 10^{9} / \mathrm{L}$ & $2.00-8.00 \times 10^{9} / \mathrm{L}$ \\
\hline Lymphocytes & $0.26 \times 10^{9} / L$ & $1.00-4.00 \times 10^{9} / \mathrm{L}$ \\
\hline Monocytes & $0.61 \times 10^{9} / \mathrm{L}$ & $0.10-1.00 \times 10^{9} / \mathrm{L}$ \\
\hline Eosinophils & $0.06 \times 10^{9} / \mathrm{L}$ & $<0.60 \times 10^{9} / \mathrm{L}$ \\
\hline Basophils & $0.02 \times 10^{9} / \mathrm{L}$ & $<0.20 \times 10^{9} / \mathrm{L}$ \\
\hline International normalised ratio & 1.7 & $0.9-1.2$ \\
\hline Prothrombin time & $18 \mathrm{~s}$ & $9-13 s$ \\
\hline Activated partial thromboplastin time & $33 \mathrm{~s}$ & $24-39 s$ \\
\hline Fibrinogen (derived) & $5.0 \mathrm{~g} / \mathrm{L}$ & $1.7-4.5 \mathrm{~g} / \mathrm{L}$ \\
\hline Sodium & $136 \mathrm{mmol} / \mathrm{L}$ & $135-145 \mathrm{mmol} / \mathrm{L}$ \\
\hline Potassium & $3.8 \mathrm{mmol} / \mathrm{L}$ & $3.5-5.2 \mathrm{mmol} / \mathrm{L}$ \\
\hline Chloride & $96 \mathrm{mmol} / \mathrm{L}$ & $95-110 \mathrm{mmol} / \mathrm{L}$ \\
\hline Bicarbonate & $29 \mathrm{mmol} / \mathrm{L}$ & $22-32 \mathrm{mmol} / \mathrm{L}$ \\
\hline Anion gap & $11 \mathrm{mmol} / \mathrm{L}$ & $4-13 \mathrm{mmol} / \mathrm{L}$ \\
\hline Osmolality & $286 \mathrm{mmol} / \mathrm{L}$ & 275-295 mmol/L \\
\hline Glucose & $5.6 \mathrm{mmol} / \mathrm{L}$ & $3.0-7.8 \mathrm{mmol} / \mathrm{L}$ \\
\hline Urea & $3.8 \mathrm{mmol} / \mathrm{L}$ & $2.1-7.1 \mathrm{mmol} / \mathrm{L}$ \\
\hline Creatinine & $73 \mathrm{mmol} / \mathrm{L}$ & $60-110 \mathrm{mmol} / \mathrm{L}$ \\
\hline Urate & $0.37 \mathrm{mmol} / \mathrm{L}$ & $0.15-0.50 \mathrm{mmol} / \mathrm{L}$ \\
\hline Protein & $65 \mathrm{~g} / \mathrm{L}$ & $60-80 \mathrm{~g} / \mathrm{L}$ \\
\hline Albumin & $27 \mathrm{~g} / \mathrm{L}$ & $35-50 \mathrm{~g} / \mathrm{L}$ \\
\hline Globulin & $38 \mathrm{~g} / \mathrm{L}$ & $25-45 \mathrm{~g} / \mathrm{L}$ \\
\hline Bilirubin (total) & $11 \mu \mathrm{mol} / \mathrm{L}$ & $<20 \mu \mathrm{mol} / \mathrm{L}$ \\
\hline Bilirubin (conjugated) & $5 \mu \mathrm{mol} / \mathrm{L}$ & $<4 \mu \mathrm{mol} / \mathrm{L}$ \\
\hline Alkaline phosphatase & $92 \mathrm{U} / \mathrm{L}$ & $45-150 \mathrm{U} / \mathrm{L}$ \\
\hline Gamma-glutamyl transferase & $39 \mathrm{U} / \mathrm{L}$ & $<55 \mathrm{U} / \mathrm{L}$ \\
\hline Alanine transaminase & $8 \mathrm{U} / \mathrm{L}$ & $<45 \mathrm{U} / \mathrm{L}$ \\
\hline Lactate dehydrogenase & $282 \mathrm{U} / \mathrm{L}$ & $120-250 \mathrm{U} / \mathrm{L}$ \\
\hline Calcium & $2.54 \mathrm{mmol} / \mathrm{L}$ & $2.10-2.60 \mathrm{mmol} / \mathrm{L}$ \\
\hline Calcium (corrected for albumin) & $2.80 \mathrm{mmol} / \mathrm{L}$ & $2.10-2.60 \mathrm{mmol} / \mathrm{L}$ \\
\hline Phosphate & $1.36 \mathrm{mmol} / \mathrm{L}$ & $0.75-1.65 \mathrm{mmol} / \mathrm{L}$ \\
\hline Magnesium & $0.70 \mathrm{mmol} / \mathrm{L}$ & $0.70-1.10 \mathrm{mmol} / \mathrm{L}$ \\
\hline C-reactive protein & $96 \mathrm{mg} / \mathrm{L}$ & $<5.0 \mathrm{mg} / \mathrm{L}$ \\
\hline
\end{tabular}

lymphadenopathy, a mediastinal mass or B symptoms.

- Histopathological diagnosis is required, ideally with an excisional lymph node biopsy.

- Given favourable survival rates, a key focus is now on monitoring and management of therapy-related complications.

\section{Authors}

John O'Bryen BSc, MBBS, FRACGP, General Practitioner, Qld. john.obryen@uqconnect.edu.au Nirija Ranjit Anderson BPharm, MBBS (Hons), Haematology Advanced Trainee, Qld

Joel Collins BSc, MBBS, FRACP, Clinical Haematologist, Qld

Competing interests: None.

Funding: None.

Provenance and peer review: Not commissioned, externally peer reviewed.

\section{References}

1. Light RW. Clinical practice. Pleural effusion. N Engl J Med 2002;346(25):1971-77. doi: 10.1056/ NEJMcp010731.

2. Lister $T A$, Crowther $D$, Sutcliffe $S B$, et al. Report of a committee convened to discuss the evaluation and staging of patients with Hodgkin's disease: Cotswolds meeting. J Clin Oncol 1989;7(11):1630-36. doi: 10.1200/JCO.1989.7.11.1630.

3. Moccia AA, Donaldson J, Chhanabhai M, et al. International prognostic score in advancedstage Hodgkin's lymphoma: Altered utility in the modern era. J Clin Oncol 2012;30(27)3383-88. doi: 10.1200/JCO.2011.41.0910.

4. Follows GA, Ardeshna KM, Barrington SF, et al. Guidelines for the first line management of classical Hodgkin lymphoma. Br J Haematol 2014;166(1):34-39. doi: 10.1111/bjh.12878

5. Arulogun S, Hertzberg M, Gandhi MK. Recent treatment advances in Hodgkin lymphoma: A concise review. Intern Med J 2016;46(12):1364-69. doi: 10.1111/imj.13051.

6. Ades L. Guidelines for the diagnosis and management of Marfan syndrome. Heart Lung Circ 2007;16(1):28-30. doi: 10.1016/j. hlc.2006.10.022.

7. Hsu CW, Wang JC, Liao WI, et al. Association between malignancies and Marfan syndrome: A population-based, nested case-control study in Taiwan. BMJ Open 2017;7(10):e017243. doi: 10.1136/bmjopen-2017-017243. 